\title{
A glorificação de um estudante poeta
}

Discurso do orador oficial do Centro Academico XI de Agosto.

O romantismo foi a grande nevróse da sensibilidade humana. Nascendo com a eclosão no mundo europeu de uma nova concepção esthetica que oppoz aos canones do classicimo uma feição nova da arte, elle iniciou ao alvorecer do século passado "a tormenta da sensibilidade" a que se refere, em primoroso estudo, Oliveira Lima.

O classicismo, apóz o movimento renovador da renascença que restituiu seiva e vigor á idealidade plastica e literaria do mundo antigo, alcançou um estado de desenvolvimento que poderemos chamar de perfeição no sentido relativo que o vocabulo possue.

Mas a perfeição, lembrava Graģa Aranha, é o signal do principio da decadencia e da morte. "A esculptura começou a declinar quando attingiu a perfeição de Phidias e a poesia latina morreu com Virgilio, Horacio e Ovidio". E assim em todos os sectores da arte, a perfeição é o esgotamento integral da força creadora. 
Deante do afrouxamento das fibras creadoras do classicismo, um novo movimento literario se esboça, para logo depois saccudir a alma da humanidade na vibração das emoções mais puras.

Hegel estabelece como fundamento da arte romantica o espirito que, sentindo a impotencia do ideal classico para represental-o, se eleva até si mesmo e em si encontra o que antes procurava no mundo sensivel.

Se a renascença, pelo seu aspecto naturalista, póde ser definida como a reacção da natureza, atravez do experimentalismo, contra o espiritualismo medieval, o romantismo, inicialmente, poderá tambem ser considerado segundo o testemunho do pensador germanico, como a reacção do espirito que não encontrava realidade que lhe correspondesse dentro das formulas estabelecidas pelo classicismo.

A vida objectiva e subjectiva assumem cambiantes novas e nuances inéditas. Surge a allucinação de desejar intensamente o vago e o impreciso. A necessidade do soffrimento, a creação dos proprios desesperos. A apathia das grandes tristesas. O mal do século. E esse sopro que afrouxava o pragmatismo vitalisava a força creadora. Era aquelle instante maravilhoso da literatura a que allude o pensador da "Esthetica da Vida". Era aquelle momento em que os valores se renovam e a arte recebe em suas veias um sangue mais quente que lhe traz a essencia da vida renovada nas fontes eternas da genialidade humana.

A visão romantica abriu o século passado. O seu clarão difundiu-se por todo o mundo, com tons macios de alvorada, annunciando para as letras um novo sol cujo esplendor meridiano viria no Brasil illuminar a fronte juvenil daquelle ante cuja memoria a patria hoje vem, genuflexa, orar e cultuar.

Espirito de profunda delicadesa e amadurecido precócemente no contacto do livro, Alvares de Azevedo adolesceu no choque tremendo da vida interior com o drama da vida objectiva e real. Toda a tragédia de quem quer e anceia, de quem deseja e procura, de quem hesita e duvida, incide 
directamente sobre a vida e a obra de Alvares de Azevedo. Em toda a sua obra presente-se o rumor lancinante dos grandes conflictos da alma humana, entenebrece as suas paginas, por vezes, a sombra dos grandes enigmas, percebe-se o anceio das soluções definitivas do erro que busca a verdade e do ephemero que aspira o eterno. - Encontrou na melancholia a felicidade de ser triste de que falla Victon Hugo. A elle poder-se-ia applicar a phrase de LAmartine sobre Homero "cantava como chorava tão incomparavel era na epopéa como na elegia".

Sob a influencia de tantos elementos - os mais diversos - a sua obra não obedeceu o cunho de uma directriz segura e de uma orientação clara e definida. Foi o impulso irrefreavel de um temperamento. Foi o delirio de uma alma juvenil em face da vida. Foi a irrupção turbilhonante dos sentimentos fermentados pelo genio.

Realisou o destino integral dos poétas. Passou como écho da voz divina nas sombras da terra. Soffreu a tortura de ser incomprehendido. Nos ultimos dias de sua existencia, abandonou a grandeza fugitiva do mundo exterior para recolher-se ao seu mundo introspectivo, onde as idéas e a potencialidade do pensamento lutavam contra as leis irrecorriveis da vida, como quem procura, na derradeira esperança, encontrar uma região de luz onde o seu espirito vibrasse em dôce consonancia com um ideal de belleza completa.

Já disséra um outro poéta: "da amargura invisivel das raizes é que nasce a belleza ironica das flores".

Mas, torturando a alma, caminhando sem méta, ao rumo que o ideal assignala, sangrando no caucaso ou bebendo a cicuta, ao impulso de um destino superior, o poéta caminha, sublimando o sofrimento, sagrando as epocas e eternisando a vida dos povos sobre a terra.

"Nascem, crescem, avigoram-se, florescem, decáem e sepultam-se para sempre no tumulo da historia, as nações $\mathrm{e}$ os heroes, por mais proceras e giganteas que o destino lhes talhasse a estatura e as proporções", dizia Latino Coelfo 
ao traçar o panegirico da Camões. Realmente. Que aconteceria ao reino portuguez conquistado, na phrase do grande estylista, pelos heróes "que cursavam oceanos ainda virginaes, tomando o rouco estridor das tempestades pelo hymno triumphal das esplendidas victorias", se não existisse aquella "vóz eloquente que resume em seus magicos accentos a altivez e a gloria de Portugal"?

Poderão passar a edades heroicas, poderão na historia succeder as epochas, poderão engolphar-se na sombra da decadencia os esplendores das civilisações, mas aquelles que reflectiram os seus pensamentos, que eternisaram os seus sentimentos, que marmorisaram as suas idéas e que sonorisaram na musicalidade poetica as vózes profundas de sua alma, esses hão de cantar, de fulgir na tenébra da decadencia, no fragor da demolição ou na melancholia silenciosa das ruinas.

Por um symbolo do que affirmamos vale a significação da noite de hoje. Pouco muito pouco, resta a São Paulo da vida romantica e bohemia de Alvares de Azevedo. E o que assistimos na noite de hoje, em meio ao rumor áspero do nosso progresso, é uma sincope do presente e o ressurgir do passado. E nesta metropole onde elle sentiu as primeiras pulsações da vida, onde se lhe desabrochou o espirito e onde á luz dos primeiros triumphos se lhe esbateu a madrugada do genio, cessa o ruido da civilisação, adormece o camartello do trabalho e um povo todo se abriga ao ambiente sagrado desta casa de ensino para a glorificação de um estudante poéta.

E a mocidade academica que nas tradições desta casa abebéra a lição para o porvir, mais de uma vez, na data commemorativa do centenario do nascimento de Alvares DE Azevedo, vem proclamar a eternidade do seu nome e de sua memoria no coração da juventude que é o proprio coração da patria brasileira.

Tenho concluido. 